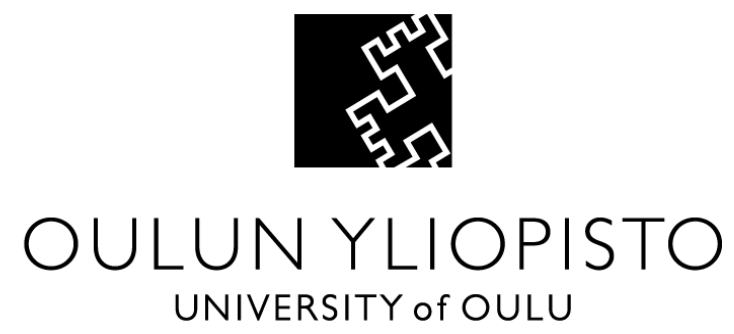

THE DEGREE PROGRAMME IN MECHANICAL ENGINEERING

WEAR-RESISTANT MATERIALS

Joel Kronqvist

\title{
BACHELOR'S THESIS
}

2016

Supervisor: Jouko Leinonen, Co-supervisor: Ilkka Miettunen 


\section{ABSTRACT}

Wear-resistant materials

Joel Kronqvist

University of Oulu, Degree Programme of Mechanical Engineering

Bachelor's thesis 2016, xx p. + yy p. appendixes

Supervisor: Jouko Leinonen, Co-supervisor: Ilkka Miettunen

Materials used in wear-resistant applications are exposed to heavy loads and different environmental circumstances which generate mechanical wear and corrosion. By choosing the most suitable materials for the correct applications, you can affect the lifetime of the machine and create substantial cost savings.

This thesis displays wear-resistant steels but also other wear-resistant materials, including irons, ceramics and polymers. Use of the materials is divided by the application. For dry applications with mechanical wear carbon steels are the optimal choice and for corrosion and tribo-chemical wear stainless steel is the correct material.

Keywords: wear-resistance, steel, materials 


\section{OPENING WORDS}

The meaning of this thesis was to define what is wear and which are the materials being used in these applications. The thesis was made for the research unit of material engineerin in University of Oulu. I would like to thank you my supervisor Jouko Leinonen for providing the comments and Ilkka Miettunen for the material sources and general helping of this thesis.

Oulu, 5.4.2016

Joel Kronqvist 


\section{TABLE OF CONTENTS}

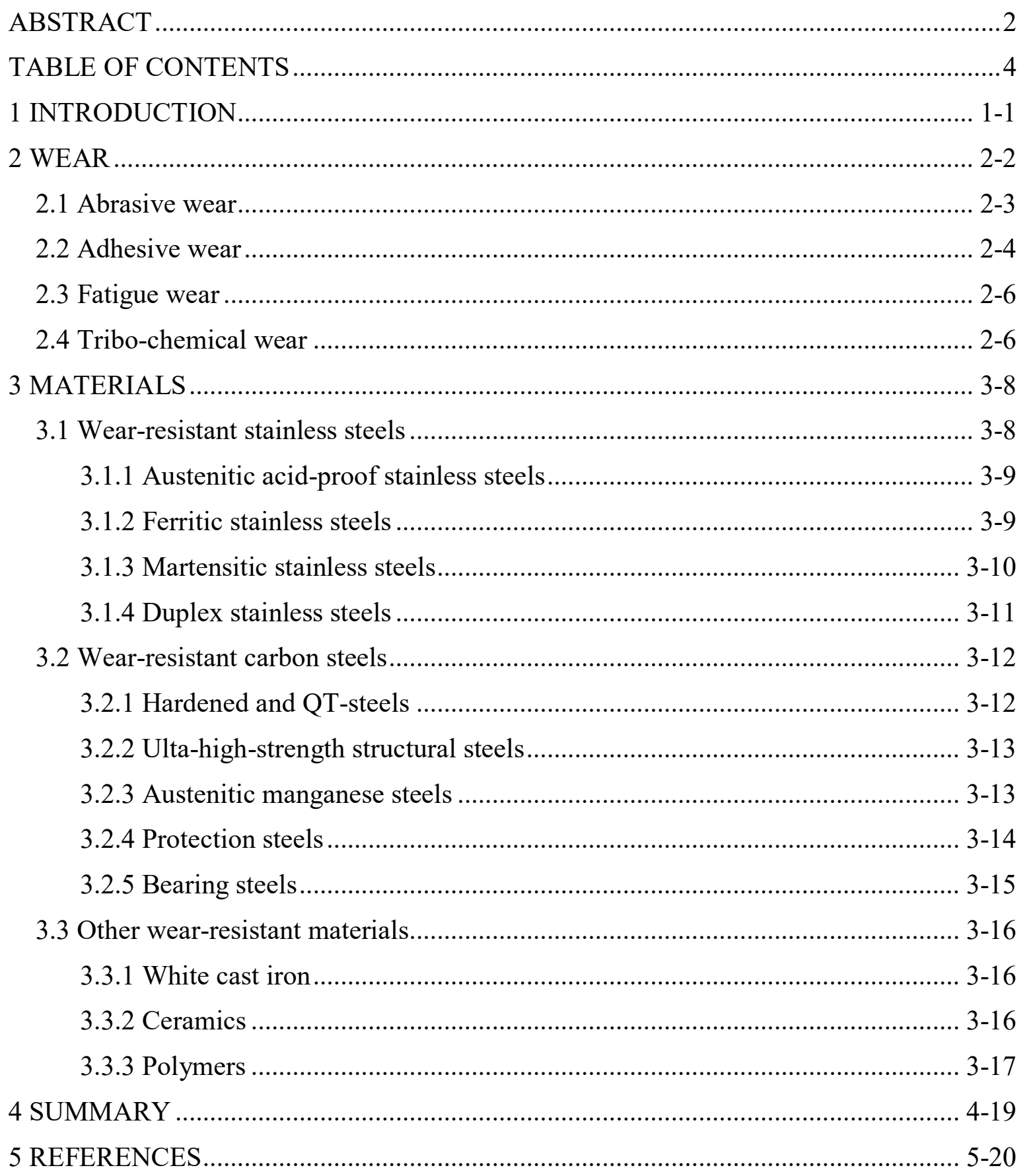




\section{INTRODUCTION}

This thesis is a literature report from wear-resistant materials. The objective was to define what exactly wear is and which materials are suitable for wear applications. The subject was decided with the personnel of materials engineering research unit.

I noticed that there is many different ways to define groups for different wear mechanisms. I outlined this thesis into four different mechanisms of wear: adhesive, abrasive, fatigue and tribo-chemical.

Even though the name of the thesis is wear-resistant materials, I mainly concentrated on wear-resistant steels. This was because steels are the most used materials in wearresistant applications due to the overwhelming mechanical properties on a decent price.

This thesis was inspired by a technical report by Tiina Rissanen, "Kaivosteollisuuden teräkset". Her report covered steels that are used in wear-resistant applications in mining industry. Also, she divided the wear mechanisms decently. 


\section{WEAR}

Wear is a tribologic phenomenon which causes material loss on surface by means of several different mechanisms. Wear can happen in many different ways and in many different cicumstances which is why dividing wear to different classes can be difficult. During the years, there has been developed several ways of classification but in this thesis I am going to classify the mechanisms of wear on the following way:

- Abrasive wear

- Adhesive wear

- Fatigue wear

- Tribo-chemical wear

In addition, we can classify different types of wear which cause activation of mechanisms listed earlier:

- $\quad$ Sliding

- Rolling

- Impact

- Vibration

- Erosion

- Gas erosion

- Cavitation

- Drop erosion

- Corrosion erosion

Even though the mechanisms above are shown as separate, in real life applications they work one after the other and in tandem. Due to the many parameters that affect to the wear process, it is very difficult to define wear unambiguously by math and physics. However, one basic rule is that higher hardness of the material increases wearresistance. [1] 


\subsection{Abrasive wear}

Abrasive wear i.e. grinding wear is defined as the loss of material due to hard particles or hard protuberances that are forced against and move along a solid surface. This mechanism of wear can be divided into two different cases: two body wear and three body wear. In two body wear the wear of the softer material is caused by the asperities on the harder surface. If the wear is caused by a hard particle trapped between the rubbing surfaces it is called three body wear. The amount of wear depends on the material properties of the rubbing surfaces. In practice the wear starts with two body wear but advances into three body wear after particles are loosening between surfaces. $[1,15,16]$

Two body abrasive wear
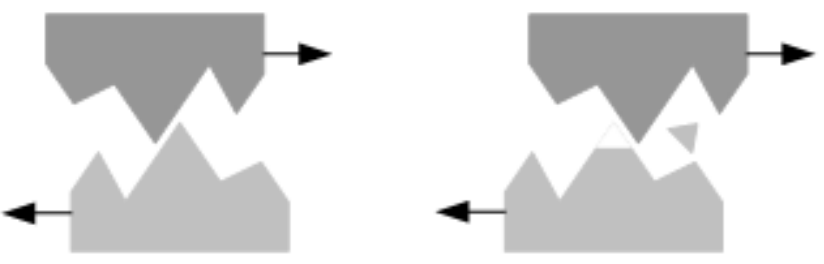

Three body abrasive wear
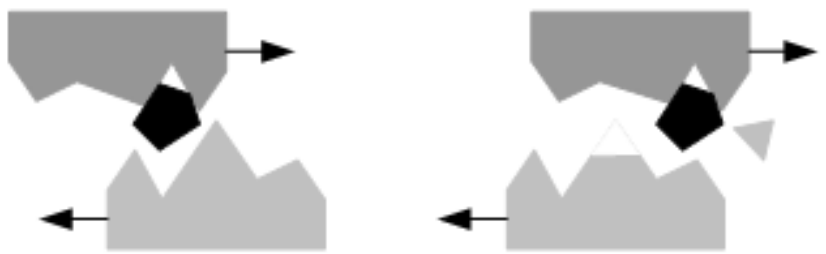

Figure 1. Abrasive wear between two and three particles. [16]

Abrasive wear can happen by three different mechanisms:

- Ploughing

- Cutting

- Cracking

Scratches, grooves and in hard materials fractures can appear in a surface with abrasive wear. Wear products usually are chips or fragile particles. Grinding abrasion wear, 
which is a combination of abrasion and pressure, typically appears in applications in which small and hard particles are crushed by powdering. These applications are for example grinding mills, crushers, stirring platforms and coating knives. [1]

One of the forms of abrasive wear is erosion wear which means that the material falls off the coating due to the collision between form or liquid particles. Erosion wear appears typically in pumps and in pipes which contain solid particles, for example soil. Erosion rate depends on the collision angle of the wear particles. In tough materials $20^{\circ}$ collision angle increases the erosion rate. [1]

\subsection{Adhesive wear}

Adhesive or so called adherence or welding wear is a result of micro junctions caused by welding between the opposing asperities on the rubbing surfaces of the counterbodies. In adhesive wear, two surfaces slide against each other and the peaks adhere to one another due to the friction joints caused by friction heat and atomic bonds. $[1,16]$

Pure adhesive wear doesn't usually appear in long periods of time but it acts as an executor for other wear mechanisms. For example, due to the adhesive wear, some particles might fall between the pieces and accelerate the wear process through other wear mechanisms, like abrasion. [1]

\section{Adhesive wear}

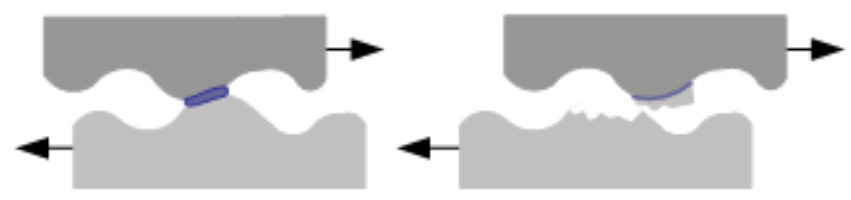

Figure 2. Adhesive wear. [16]

Distinctive marks for surface with adhesive wear are 
- Appearance of polished and formed areas

- Blisters and pits

- Loose particles on the surface

- Movement of the material from one component to another

Typically wear appears in metal pieces that are spinning or trailing against each other, for example in axels against bearing surface, ring of the chain against the roll and rolls of the steel factory. [1]

One of the forms of wear is vibration wear which means back and forth movement between the opposite surfaces. Small amplitude movement first causes welding between the surfaces and after this continuous vibration tears the junction apart. This causes loose particles between the surfaces which can continue wear of the surface through the abrasion mechanism. $[1,16]$

Tangential cycling load

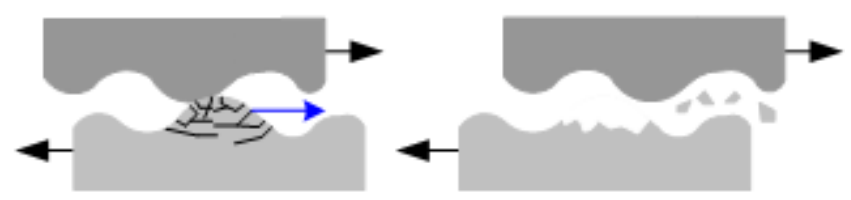

Figure 3. Vibration wear. [16]

The factors decreasing adhesive wear are

- Lower load

- Harder rubbing materials

- Contaminated rubbing surfaces 
- Solid lubricants

- Anti-wear additives in oil.

\subsection{Fatigue wear}

Fatigue wear of a material is caused by a cycling loading during friction. Fatigue occurs if the applied load is higher than the fatigue strength of the material. When the ledge of the surface roughness is deformed many times enough, wear particles starts to loose due to the fatigue crack. Fatigue crack starts at the material surface and spreads to the subsurface regions. If the wear is not clearly abrasive or adhesive, it usually is fatigue wear. $[15,16]$

\section{Fatigue wear of an overlay}

Normal cycling load

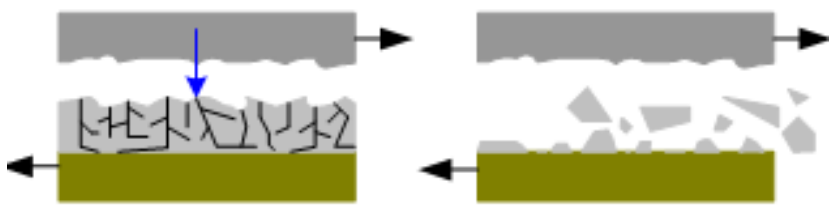

Figure 4. Fatigue wear. [16]

Cavitation is one of the forms of fatigue wear, which is caused by fatigue impacts towards the metal surface. When the pressure of the running liquid changes, the gas bubbles in the liquid collapse. When the bubble collapses, it disengages energy which causes wear. Due to the cavitation the surface of the metal becomes rough. Also erosion can cause fatigue wear when the material is tough. Impacting particles cause slow wear and the material has time to work-harden until the particles loose due to the fatigue. [1]

\subsection{Tribo-chemical wear}

Normally the surface of the metal is covered by oxide coating which reduces erosion rate and friction and protects from corrosion. Tribochemical-wear means that the oxide 
coating wears due to a differential motion. This motion breaks the oxide coating and the bare metal surface reacts again with the environment. [1]

One of the forms of tribo-chemical wear is corrosion wear. This means that the surface of the metal is simultaneously or by turns exposed to corrosion and wear on different mechanisms. Corrosion wear typically starts by chemical or electrochemical process but often also by mechanical wear. Mechanically loosened coating exposes new surface open to corrosion. [1]

Stainless steel is a good choice for corrosive applications because it forms a new chromium oxide surface layer after the old one breaks. The layer usually breaks in acidferous circumstances and it protects the surface from corrosion. There are many different steels in the market and the choice depends on the application and demanded mechanical properties. For example stainless duplex steel is a great choice for pipes due to its higher strength and hardness comparing to austenitic stainless steel. Higher mechanical properties means higher wear-resistance against different particles. [1] 


\section{MATERIALS}

Material choice can be made on the basis of the dominant wear mechanism which means that compromises must be made between the following properties: [17]

- Friction factor in surface

- Solubility between the metals

- Self-lubrication

- Corrosion resistance

- Hardenability and maximum hardness

- Elastic deformability

- Machinability or accessible surface quality.

\subsection{Wear-resistant stainless steels}

Wearing and demanding conditions (moisture, temperature, $\mathrm{pH}$ level, chloride and sulphate, biological growth. etc.) expose materials to corrosion. Corrosion resistance for carbon steels can be improved with different coatings but for demanding and critical applications stainless steel is a good choice. Corrosion resistance in stainless steels is based on chromium oxide surface layer which separates steel from corrosive environment. Wide operating temperatures are also an advantage. [1]

Wear-resistant stainless steels can be divided to austenitic, martensitic, ferritic and duplex-steels. These groups include structural, heat resisting and acid-proof steels. [1] 


\subsubsection{Austenitic acid-proof stainless steels}

Austenitic acid-proof stainless steels differ substantially from more conventional grades with regard to resistance to corrosion and, in some cases also mechanical and physical properties. This is mainly due to the high contents of chromium, nickel, molybdenum and nitrogen. Especially molybdenum (2-3\%) increases corrosion resistance. Typical yield strength for acid-proof stainless steels varies from 260 to $320 \mathrm{MPa}$ on hot-rolled condition. Hardness is significantly lower comparing to QT steels, only $160 \mathrm{HB}$ for EN 1.4401. $[1,10,11]$

Acid-proof stainless steels are mainly used in following applications:

- Process equipment in chemical industry

- Hydrometallurgy

- Heat exchangers

Even though the alloying is pretty high, all these steels are well suited for welding. However, due to their stable austenitic structure, they are somewhat more sensitive to hot cracking in connection with welding and generally welding should be performed using low heat input. Austenitic stainless steel work-harden quickly and this, together with their high toughness, means that they are often perceived as problematic from a machining perspective. However, with the right set of tools, tool settings and cutting speed, theses materials can be successfully machined. [10]

\subsubsection{Ferritic stainless steels}

Normally ferritic stainless steels don't contain expensive alloying element nickel and are a good alternative for different applications. Low-chormium $(11,5 \% \mathrm{Cr})$ ferritic structural steel EN 1.4003 is one of the most suitable for wear-resistant applications. This steel contains also low amounts of nickel and manganese (see table 1) and typical applications include tubes, water heaters, storage tanks. Although corrosion resistance in strong acids is limited, comparing to carbon steels it is good. [1, 12] 
Table 1. Chemical composition of a ferritic stainless steel grade 4003. [12]

\begin{tabular}{c|cccc|cccccr} 
Grade & EN & ASTM & UNS & JIS & C & N & Cr & Ni & Mo & Others \\
\hline 4003 & 1.4003 & - & S40977 & - & 0.02 & - & 11.5 & 0.5 & - & -
\end{tabular}

Ferritic stainless steels are usually a bit stronger than austenitic steels. Typical yield strength for EN 1.4003 in room temperature is $340 \mathrm{MPa}$ when yield strength for austenitic EN 1.4401 is $280 \mathrm{MPa}$. Impact toughness for EN 1.4003 is on the same level as modern carbon steels which means that comparing to other ferritic steels it is significantly higher. [1]

Ferritic grades can be readily cold-formed by all standard processes. Their forming properties are similar to those of low alloyed carbon steels. Machining characteristic are similar to those of low alloyed carbon steels with tensile strength of $500 \mathrm{MPa}$. Consequently, the guidelines regarding the machining parameters and tools given for the low alloyed carbon steels can be used. Modern ferritic stainless steels are readily weldable with conventional welding methods. [12]

\subsubsection{Martensitic stainless steels}

Martensitic stainless steels are not as corrosion-resistant as austenitic grades or not as hard and strength as hardened carbon grades. However, martensitic stainless steels have the best combination of wear and corrosion resistance and the highest hardness and strength of the stainless steel family. Martensitic microstructure is almost always ensured by hardening. [13]

Typical wear-resistant applications are knife blades, brake disks, mechanical parts subject to wear and surgical cutting tools. Chromium percentage is usually around $13 \%$ which gives 600-800 MPa tensile strength depending on the grade. Due to a quite high percentage of carbon, welding can be difficult. [13, 19] 


\subsubsection{Duplex stainless steels}

Ferritic-austenitic stainless steel also referred to as duplex stainless steels, combine many of the beneficial properties of ferritic and austenitic steels. Due to the high content of chromium and nitrogen, and often also molybdenum, these steels offer good resistance to localized and uniform corrosion. The duplex microstructure contributes to the high strength and high resistance to stress corrosion cracking. Due to the lower nickel content, the price of duplex steel is more stabile than austenitic stainless steels. $[14,1]$

Table 2. Chemical composition of different duplex stainless steel grades. [14]

\begin{tabular}{|c|c|c|c|c|c|c|c|c|c|c|}
\hline \multirow{2}{*}{$\begin{array}{l}\text { Outokumpu } \\
\text { Steel name }\end{array}$} & \multicolumn{4}{|c|}{ International steel No } & \multicolumn{6}{|c|}{ Chemical composition, $\%$ by wt. Typical values } \\
\hline & EN & ASTM & UNS & Iso & c & $\mathbf{N}$ & $\mathrm{Cr}$ & Ni & Mo & Others \\
\hline LDX $2101^{\circ}$ & 1.4162 & - & S32101 & 4162-321-01-E & 0.03 & 0.22 & 21.5 & 1.5 & 0.3 & $5 \mathrm{Mn} \mathrm{Cu}$ \\
\hline $2304^{1}$ & 1.4362 & - & S32304 & 4362-323-04-I & 0.02 & 0.10 & 23.0 & 4.8 & 0.3 & $\mathrm{Cu}$ \\
\hline LDX $2404^{\circ}$ & 1.4662 & - & S82441 & $4662-824-41-X$ & 0.02 & 0.27 & 24.0 & 3.6 & 1.6 & $3 \mathrm{Mn} \mathrm{Cu}$ \\
\hline 2205 & 1.4462 & - & S $32205^{2}$ & 4462-318-03-1 & 0.02 & 0.17 & 22.0 & 5.7 & 3.1 & \\
\hline 4501 & 1.4501 & - & S32760 & 4501-327-60-I & 0.02 & 0.27 & 25.4 & 6.9 & 3.8 & W Cu \\
\hline 2507 & 1.4410 & - & S 32750 & 4410-327-50-E & 0.02 & 0.27 & 25.0 & 7.0 & 4.0 & \\
\hline
\end{tabular}

Due to the diversified properties these steels can be used in many industries and applications. [14]

Typical applications include:

- Storage tanks

- Pressure vessels

- Heat exchangers

- Water heaters

- Reinforcing bars for concrete structures.

Duplex steels are significantly stronger in room temperature than for example regular structural steel S355. Typical yield strength for EN 1.4462 is $510 \mathrm{MPa}$ in hot-rolled 
condition. However, ultimate elongation is lower than in austenitic steels due to the high strength. For 1.4462 elongation is $35 \%$. [14]

Duplex stainless steel is suitable for all forming processes available for stainless steel.

The high proof strength compared to austenitic and ferritic stainless steel can impose some differences in forming behaviour depending on chosen forming technique, such as an increased tendency to springback. This point is particularly relevant to forming of any high strength steel. If the forming process is not already decided, it is certainly possible to choose the most suitable one for duplex grades. Moreover, an excellent interplay between high proof strength, work hardening rate and elongation promote the duplex grades for light weight and cost-efficient applications with complex shapes. [14]

Duplex steels generally have good weldability and can be welded using most of the welding methods used for austenitic stainless steel. [14]

\subsection{Wear-resistant carbon steels}

Wear resistant carbon steels usually contain boron and chromium. The steels are hard but also weldable due to the low carbon content. Typically wear-resistant steels have a martensitic microstructure which makes the steel hard, strong and wear-resistant. [1]

\subsubsection{Hardened and QT-steels}

QT-steels are martensitic and abrasion resistant steels which have been tailored for various solutions. Hardened wear-resistant steels are tempered in low temperatures (100-200 $\left.{ }^{\circ} \mathrm{C}\right)$ in order to increase the toughness. If the tempering is made in higher temperatures $\left(450-680{ }^{\circ} \mathrm{C}\right)$, it is called quenched and tempered steel. The hardness of the QT-steel is significantly lower than hardened steel. [3]

Hardox is the brand name for wear resistant steels from SSAB. Hardness for Hardox 400 is $400 \mathrm{HV}$ and yield strength $1000 \mathrm{MPa}$. Chemical composition includes $0.15 \% \mathrm{C}$ 
and other alloys as manganese, chrome, nickel, molybdeum and boron. The accurate chemical composition is shown in table 3. [4]

Table 3. Chemical composition of different grades of Hardox. [4]

\begin{tabular}{|l|c|c|c|c|c|c|c|c|c|}
\hline \multicolumn{10}{|c|}{ Chemical Composition (ladle analysis) } \\
\hline Steel grade & $\begin{array}{c}\text { C } \\
\text { Max \% }\end{array}$ & $\begin{array}{c}\text { Si } \\
\text { Max \% }\end{array}$ & $\begin{array}{c}\text { Mn } \\
\text { Max \% }\end{array}$ & $\begin{array}{c}\text { P } \\
\text { Max \% }\end{array}$ & $\begin{array}{c}\text { S } \\
\text { Max \% }\end{array}$ & $\begin{array}{c}\text { Cr } \\
\text { Max \% }\end{array}$ & $\begin{array}{c}\text { Ni } \\
\text { Max \% }\end{array}$ & $\begin{array}{c}\text { Mo } \\
\text { Max \% }\end{array}$ & $\begin{array}{c}\text { B } \\
\text { Max \% }\end{array}$ \\
\hline Hardox HiTuf & 0.20 & 0.60 & 1.60 & 0.020 & 0.020 & 0.70 & 2.0 & 0.70 & 0.005 \\
\hline Hardox 400' & 0.15 & 0.70 & 1.60 & 0.025 & 0.010 & 0.50 & 0.25 & 0.25 & 0.004 \\
\hline Hardox 4502 & 0.18 & 0.25 & 1.30 & 0.015 & 0.004 & 0.10 & 0.10 & 0.04 & 0.003 \\
\hline Hardox 450 & 0.26 & 0.70 & 1.60 & 0.025 & 0.010 & 1.40 & 1.50 & 0.60 & 0.005 \\
\hline Hardox 500 & 0.30 & 0.70 & 1.60 & 0.020 & 0.010 & 1.50 & 1.50 & 0.60 & 0.005 \\
\hline Hardox 550 & 0.37 & 0.50 & 1.30 & 0.020 & 0.010 & 1.40 & 1.40 & 0.60 & 0.004 \\
\hline Hardox 600 & 0.47 & 0.70 & 1.00 & 0.015 & 0.010 & 1.20 & 2.50 & 0.70 & 0.005 \\
\hline Hardox Extreme & 0.47 & 0.50 & 1.0 & 0.015 & 0.020 & 1.20 & 2.50 & 0.80 & 0.005 \\
\hline
\end{tabular}

\subsubsection{Ulta-high-strength structural steels}

Nowadays ulta-high-strength structural steels have so high yield strength that the hardness is comparable to the wear-resistant steels. SSAB produces Strenx 1300 which has a minimum yield strength of $1300 \mathrm{MPa}$ and minimum hardness of $400 \mathrm{HB}$. This hardness is twice than in ordinary structural steel S355. [1,5]

Ultra-high-strength steels allows lighter structures and thinner material thicknesses. Typical applications include load-carrying structures that place very high demands on low weight, for example chassis and superstructures for commercial vehicles. Prices for ultra-high-strength structural steels are obiviously higher than steels with low strength but in high demand applications cost-effiency is better due to the lighter structure and manufacturing speed. [6]

\subsubsection{Austenitic manganese steels}

Austenitic manganese steels are being used in wear-resistant applications as they have combined high toughness and ductility with high work-hardening capacity and, usually, 
good resistance to wear. Manganese steels are produced as cast components and the austenitic microstructure is obtained by heat treatment. The chemical composition usually includes $0,7-1,45 \% \mathrm{C}, 11-14 \% \mathrm{Mn}$ and other alloys as chrome, nickel and molybdenum. The wear resistance of manganese steel is based on a work hardening phenomenon. Initial hardness is approx. 220-250 HV but hardness of the work hardened layer can be up to $600 \mathrm{HV}$ in primary applications. The depth and hardness of work hardened surface vary depending on application and Mn-steel grade. [1, 2, 3]

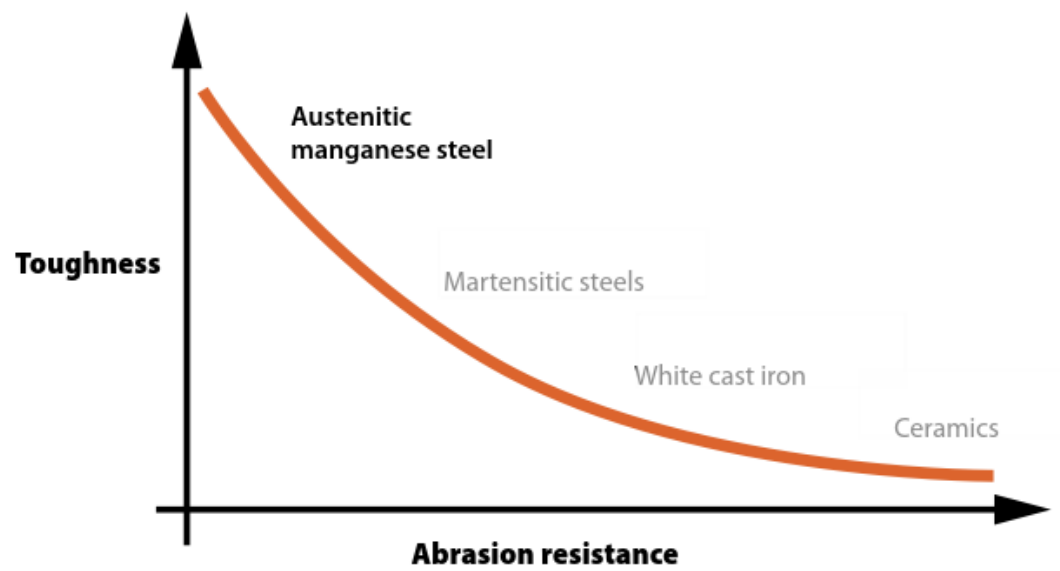

Figure 5. Abrasion resistance versus toughness. [3]

\subsubsection{Protection steels}

Protection steels have excellent ballistic properties in combination with high hardness and strength. SSAB gives Ramor 450 mechanical properties of $450 \mathrm{HBW}$ hardness and $1100 \mathrm{MPa}$ yield strength. This means that protection steels have a bit higher strength values comparing to wear-resistant steels. These properties are an advantage in some structure applications. $[1,8]$

Protection steels have been developed for applications where blast protection or high ballistic resistance is required. These kind of applications are for example:

- Doors 
- Walls

- Window frames

- Secured containers

Due to hardening, protection steels are not recommended being used in high temperature applications as properties obtained by hardening tend to reduce while the temperature is increasing. $[1,8]$

Table 4. Chemical composition of a ballistic steel. [7]

\begin{tabular}{|l|l|l|l|l|l|l|l|l|}
\hline $\begin{array}{l}\left.\mathrm{C}^{*}\right) \\
(\max \%)\end{array}$ & $\begin{array}{l}\left.\mathrm{Si}{ }^{7}\right) \\
(\max \%)\end{array}$ & $\begin{array}{l}\left.\mathrm{Mn}{ }^{*}\right) \\
(\max \%)\end{array}$ & $\begin{array}{l}\mathrm{P} \\
(\max \%)\end{array}$ & $\begin{array}{l}\mathrm{S} \\
(\max \%)\end{array}$ & $\begin{array}{l}\mathrm{Cr}{ }^{1)} \\
(\max \%)\end{array}$ & $\begin{array}{l}\text { Ni }{ }^{1)} \\
(\max \%)\end{array}$ & $\begin{array}{l}\text { Mo ") } \\
(\max \%)\end{array}$ & $\begin{array}{l}\mathrm{B} \text { ") } \\
(\max \%)\end{array}$ \\
\hline 0.32 & 0.4 & 1.2 & 0.015 & 0.010 & $1.01)$ & $1.81)$ & 0.7 & 0.005 \\
\hline
\end{tabular}

Chemical analysis is similar to wear-resistant steels (Table 2). Weldability and machinability are good due to the reasonable alloying. Welding can be done on all regular welding methods. Drilling can be performed using high-speed steel drills or cemented carbide drills. [9]

\subsubsection{Bearing steels}

Bearings are subject to the toughest of working conditions. Materials demand good wear-resistance, fatigue strength and surface compression resistance. Typical steel for small bearings is only alloyed by chromium: C 1,0\%, Cr 1,0\%. [13]

Due to the high content of carbon, martensitic matrix of hardened steel is full of hard carbide crystals and chromium increases their wear-resistance. On some cases low amounts of molybdenum are used which also increase the hardness of the carbide. Second main fuction of chromium is to make the steel through hardenable because the soft core under the hard surface would otherwise remain lower fatigue strength. Due to this, steels used for big ball and cylinder bearings contain higher amounts of chromium. [13] 
Due to high fatigue strength, ball bearing steels have to be particulally pure from slag inclusions and gas porosities. This is why manufacturing includes vacuum processing of the melt and oxygen protected cast. [13]

\subsection{Other wear-resistant materials}

Other wear-resistant materials are also included in this thesis. These materials are not as widely used as steels but can be preferred in some applications.

\subsubsection{White cast iron}

White iron is a useful material in applications which require really high wear-resistance. Usually the best combination of wear-resistance and toughness is gained by rich alloying. [13]

For example chromium cast steel: C 2,6 \%, Cr 27\%, Mo 2\%. Hardness as hardened is about $600 \mathrm{HB}$. [13]

Crystal structure of this iron is established from hard alloy carbide, martensite and work hardenable austenite. Suitable applications include grinding balls for grinding of ore, limestone and cement clinker and wear-resistant parts of a centrifugal blasting machine. [13]

So called Ni-Hard cast irons are used especially for the wear-resistant parts of the concrete industry. Ni-Hard irons usually contain $2 \% \mathrm{Cr}$ and $4 \% \mathrm{Ni}$. Microstructure is composed from martensite and carbide and the typical hardness is around $600 \mathrm{HB}$. Acronym for standard white iron is EN-GJN (No graphite). [13]

\subsubsection{Ceramics}

Ceramic is a high temperature-resistant, inorganic and non-metallic material which is manufactured from powder and gets the final shape of the product in high temperature 
hardening (500 celsius degree). Ceramics possess higher hardness, good chemical resistance and, on occasion, much greater wear resistance than most metals. However, creamics have one big weakness comparing to metals, lack of toughness. [13]

Technical ceramics is a material name for new ceramic materials which have been developed for technical and scientic applications. Source materials for technical ceramics are pure syntetic oxides, borides, carbides and nitrides. Typical hardness for engineering ceramics varies depending a lot on the material composition. For hot pressed silicon carbide the hardness is $2600 \mathrm{HV}$ and for alumina the hardness is 1600 HV. $[13,18]$

Cermet is a metal alloy which contains wolfram, chrome or titanium carbide particles in softer and more flexible cobolt-nickel base metal. This results a material which has higher toughness than ceramic and higher hardness and high-temperature resistance than metal. [13]

Ceramic matrix composites are modified ceramics which can have higher strength and fracture toughness and better reliability compared to unmodified ceramics. These composites consist of a ceramic matrix of alumina, silicon carbide, silicon nitride, carbon or glass, with ceramic or metallic fibres. The development of ceramic composites and testing is relatively new. [18]

\subsubsection{Polymers}

Polymers are materials which are formed by the polymerization of hydrocarbons and are used to describe a huge amount of different substances. Many of these materials were not meant to use in bearing or in wear-resistant applications but some of the polymers have great tribological properties. [18]

Most commonly used polymers for friction and wear components are POM, PA, PTFE and UHMWPE. For example polytetrafluoroethylene (PTFE) has low friction but high wear rate and high operating temperature limit. It is usually blended with other polymers or reinforced as a composite materials. PTFE has a tensile strength of $10 \mathrm{MPa}$ but significantly higher values are reported under spesific conditions. [18] 
Most polymers used in engineering applications are blends of different polymers and additives. For example nylon with PTFE or PTFE reinforced with glass. Applications include bearings, gears and wear strips in power transmission machines. [18] 


\section{SUMMARY}

Suitability of the material depends a lot on the application. If the environment is not corrosive, the best choice is wear-resistant carbon steels. On the other hand, if the material is in contact with acids or applications are highly corrosive, only option is to use more expensive stainless steel. Mining industry is perhaps the most important application for the wear-resistant materials. This industry uses mainly carbon steels, including hardened and manganese steels. Structures can be from cutted plate or as cast.

Polymers can provide low friction and wear coefficients but their use is limited to low temperatures, speeds and loads. Ceramics usually have good mechanical properties and resistance to high temperatures but require very high temperatures for processing and this way are expensive and difficult to manufacture. Polymers and ceramics are in the developing stage and tribological applications for these materials are really rare. Much is expected from the development before these materials become more widely used.

When choosing a wear-resistant materials, several things should be taken into account. Mechanical properties, especially hardness and toughness, must be defined by the application. By increasing hardness you almost exclusively decrease toughness. This creates problems with usability, processibility and formability. Even though polymers and ceramics can be interesting in the future, the availability, formability, weldability and price makes steel the most suitable choice for wear-resistant applications. 


\section{REFERENCES}

1. Rissanen T (2014) - Kaivosteollisuuden teräkset, Rovaniemi: Lapin Ammattikorkeakoulu

2. http://www.totalmateria.com/page.aspx?ID $=$ CheckArticle $\& L N=F I \&$ site $=$ kts $\& N$ $\underline{M=69}$-website

3. Metso Oyj, Wear and materials application guide. Downloadable from: http://www.metso.com/miningandconstruction/MaTobox7.nsf/DocsByID/23A01 81E98D2FA3AC2257856002E27C2/\$File/Wear and materials en.pdf

4. SSAB AB, Welding of Hardox. Downloadable from: http://www.ssab.fi//media/Files/EN/Hardox/Brochures/103-EN-Welding-of-Hardox.pdf

5. SSAB AB, Material sheet for Strenx 1300. Downloadable from:

http://www.ssab.com/api/sitecore/ProductPdfRender/PrintProductSheet?pid=724 1274AC1674478A3002C21033DB1D7

6. Lämsä J. \& Kiuru H. Ultralujat rakenne- ja kulutusteräkset - tärkeimmätominaisuudet suunnittelulle. Raahen Seudun Teknologiakeskus Oy \& Oulun Yliopisto, 2012

7. SSAB, Armox $500 \mathrm{~T}$ brochure: hhttp://www.ssab.fi/api/sitecore/ProductPdfRender/PrintProductSheet?pid=ACD 3681501884BA2B09D742FE19A0F7F

8. Ruukki Ramor protection steel brochure (2014): http://www1.ruukki.com/Steel/Hot-rolled-steels/Ramor-protection-steel/Ramorprotection-steel\#

9. SSAB's Armox workshop recommendations. Downloadable from: https://www.google.fi/url?sa=t\&rct=j\&q=\&esrc=s\&source=web\&cd=2\&cad=rja $\underline{\text { \&uact }=8 \& \text { ved }=0 \text { ahUKEwjotODstfnKAhWrIJoKHb9kAogQFggrMAE\&url=htt }}$ ps\%3A\%2F\%2Fwww.ssab.com\%2F\%2Fmedia\%2FFiles\%2FEN\%2FArmox\%2F701-Armox Workshoprecommendations.pdf\&usg=AFQjCNFBUBTtqfU9xvESzT9QwoGyNb4Fng

10. Outokumpu high performance austenitic stainless steel data sheet: http://www.outokumpu.com/SiteCollectionDocuments/Outokumpu-highperformance-austenitic-stainless-steel-data-sheet.pdf

11. Outokumpu stainless steel handbook, downloadable from: http://www.outokumpu.com/SiteCollectionDocuments/Outokumpu-stainlesssteel-handbook.pdf 
12. Outokumpu Ferricit Stainless Steel, downloadable from: http://www.outokumpu.com/SiteCollectionDocuments/Ferritic_Stainless_Steel 1.4003_1.4512_1.4016_1.4510_1.4509_1.4521_Datasheet.pdf

13. Koivisto $K$ \& Laitinen $E$ \& Niinimäki $M$ \& Tiainen $T$ \& Tiilikka $P$ \& Tuomikoski J (2008) Konetekniikan materiaalinoppi. 12.-13. painos. Helsinki: Edita Prima Oy

14. Outokumpu Duplex stainless steel, downloadable from: http://www.outokumpu.com/SiteCollectionDocuments/Outokumpu-Duplex$\underline{\text { Stainless-Steel-Data-Sheet.pdf }}$

15. Kivioja S \& Kivivuori S \& Salonen P (2007) Tribologia - Kitka, Kuluminen ja Voitelu. 5. painos. Helsinki: Hakapaino Oy

16. Substech-website. Abrasive, adhesive and fatigue wear. http://www.substech.com/dokuwiki/doku.php?id=mechanisms_of_wear\#abrasiv e wear

17. Eskelinen S (2012) - Luento 2 - Konstruktiomateriaalit, Lappeenrannan Teknillinen Yliopisto.

Downloadable: https://www.google.fi/url?sa $=$ t\&rct $=\mathrm{j} \& \mathrm{q}=\& \mathrm{esrc}=\mathrm{s} \&$ source $=$ web\&cd $=4 \& \mathrm{cad}=\mathrm{rja}$ \&uact $=8 \&$ ved $=0$ ahUKEwjvzgigNnLAhWhs3IKHY0eDoQQFgg1MAM\&url=https\%3A\%2F\%2Fnoppa.lut.fi \%2Fnoppa\%2Fopintojakso\%2Fbk20a2100\%2Fluennot\%2Fkertausluento b.pdf \&usg=AFQjCNHkgsC4ty5BuH72Wj9n0P4EiLeYYg

18. Stachowiak G \& Batchelor A (2014) Engineering Tribology. Fourth edition. Elsevier Inc.

19. Outokumpu Martensitic stainless steels: http://www.outokumpu.com/en/products-properties/more-stainless/stainlesssteel-types/martensitic-and-precipitation-hardening/Pages/default.aspx 